Review

\title{
Proteomics of heavy metal toxicity in plants
}

\author{
Petra Cvjetko ${ }^{1}$, Mira Zovko ${ }^{2}$, and Biljana Balen ${ }^{1,2}$ \\ Department of Molecular Biology, Faculty of Science, University of Zagreb ${ }^{l}$, Croatian Environment Agency ${ }^{2}$, \\ Zagreb, Croatia
}

Received in August 2013

CrossChecked in August 2013

Accepted in November 2013

\begin{abstract}
Plants endure a variety of abiotic and biotic stresses, all of which cause major limitations to production. Among abiotic stressors, heavy metal contamination represents a global environmental problem endangering humans, animals, and plants. Exposure to heavy metals has been documented to induce changes in the expression of plant proteins. Proteins are macromolecules directly responsible for most biological processes in a living cell, while protein function is directly influenced by posttranslational modifications, which cannot be identified through genome studies. Therefore, it is necessary to conduct proteomic studies, which enable the elucidation of the presence and role of proteins under specific environmental conditions. This review attempts to present current knowledge on proteomic techniques developed with an aim to detect the response of plant to heavy metal stress. Significant contributions to a better understanding of the complex mechanisms of plant acclimation to metal stress are also discussed.
\end{abstract}

KEY WORDS: heavy metal stress; mass spectrometry; plant proteome; protein biomarkers; twodimensional electrophoresis

The ever-increasing human population is in growing demand for agricultural production. Whereas global warming represents a major impediment to the increase of arable surfaces (1-3), the wide variety of human activities inherent to this demand results in an immense burden to the environment from pollutants such as metals and metalloids. For example, smelting operations, fossil fuel combustion (4), and contamination with arsenic (As)-based pesticides (5) are major sources of arsenate in environment, alongside geologically derived activities. Plants are not resistant to arsenate because it is an analogue of phosphate, competing for the same uptake carriers in the root (6). Nitrates and phosphates are also one of the major pollutants leaching to groundwater. The excessive use of nitrogen-based fertilisers and industrial effluents, as well as biological waste and landfills that have not gone through nitrification, lead to nitrogen pollution $(7,8)$. In addition, increased levels of phosphate from phosphate fertiliser industries may cause soil contamination, which is potentially hazardous to plants and groundwater (9).

The last century has seen a tremendous rise in heavy metal emission and an enormous release of these elements into soil, water, and air through sources such as industrial activity, wastewater treatment, contaminated sewage sludge, phosphate fertilizers, and various agrochemicals $(10,11)$. All metals of a specific gravity higher than $>5 \mathrm{~g} \mathrm{~cm}^{-3}$ (12) and an atomic number over 20 (13) belong to the group of heavy metals. Some, such as zinc $(\mathrm{Zn})$, iron $(\mathrm{Fe})$, manganese (Mn), molybdenum (Mo), and copper $(\mathrm{Cu})$, are micronutrients essential for physiological processes in plants, metalloproteins and ion-dependent 
enzymes such as ascorbate oxidase, cytochrome catalase, peroxidase, superoxide dismutase, nitrate reductase, etc. (14). These metals may become toxic if their concentrations exceed the levels necessary for plant metabolism (13). On the other hand, metals such as cadmium $(\mathrm{Cd})$, mercury $(\mathrm{Hg})$, and lead $(\mathrm{Pb})$ are not required for plant metabolism and can cause harmful effects even at very low concentrations. Furthermore, certain non-physiological ions are able to replace physiological ions and still perform physiological functions for a certain time without harming a plant. For instance, strontium $\left(\mathrm{Sr}^{2+}\right)$ can replace calcium ions during heat stress in moss (15).

Soil and water contaminated with toxic heavy metals pose a major environmental and human health issue. However, the metabolism of certain plants can be used to reduce the content or toxic effects of metals in the environment (16). The phytoremediation of metals refers to the use of metal-accumulating plants and their associated microbiota for environmental clean up. It is widely accepted as an environmentally friendly, non-invasive and cost-effective restoration technology attractive for the remediation of metalcontaminated sites (17).

As sessile organisms, plants are inevitably exposed to environmental concentrations of heavy metals, either geologically or through human activities (18, 19). Heavy metals enter a plant from soil and water through the root system via passive or active transport (20). After the uptake, heavy metal ions can be translocated from the root via the xylem to the aerial parts of a plant such as stems and leaves (21). Plants exposed to heavy metal stress are capable of accumulating high levels of heavy metals following an accumulation gradient in organs: roots $>$ stems $>$ leaves $>$ seeds (22). The toxic effect of certain heavy metals depends on many factors, primarily on the plant species, its stage of development, and the concentration and chemical properties of the metal.

All plants possess a basal tolerance to heavy metals, but elevated concentrations can cause harmful effects and disturbances such as transpiration and photosynthesis inhibition, disturbance of carbohydrate metabolism, nutrition stress, and oxidative stress, all of which collectively yield a general effect on plant development and growth (23). The uptake of nonessential and potentially high toxic heavy metal ions such as $\mathrm{Cd}^{2+}, \mathrm{Hg}^{2+}$, and $\mathrm{Pb}^{2+}$, as well as metalloids As (phytoavailable ion forms are arsenate, $\mathrm{AsO}_{4}{ }^{3}$-and arsenite, $\mathrm{AsO}_{3}{ }^{3-}$ ) and selene ( $\mathrm{Se}$ ) (ion forms selenate, $\mathrm{SeO}_{4}{ }^{2-}$ and selenite, $\mathrm{SeO}_{3}{ }^{2-}$ ) (21) is of major concern.
Typical symptoms of heavy metals stress are often similar to those of essential nutrient deficiency (13); weaker growth, lower biomass, necrotic spots in leaves, and damage mainly at the root level (24-26). Accumulation of higher concentrations can cause reductions in crop yields (27), but can also result in a potential threat to human health $(28,29)$ because heavy metals thus become part of the food chain.

In order to alleviate the stress and re-establish cellular homeostasis and antioxidant capacity, plants have developed highly effective mechanisms to regulate the uptake, accumulation, distribution, and detoxification of heavy metal ions (30). Vital components in these mechanisms are metal transporters responsible for metal uptake and vacuolar transport, chelators for heavy metal detoxification and tolerance, and chaperones which play a significant role in the delivery and trafficking of metal ions $(31,32)$, all of which are protein molecules. That is why the identification of protein markers could serve as a good starting point for revealing new aspects of heavy metal stress in plants (24).

\section{Proteomes and proteomics}

Ever since the completion of genome sequencing projects on many model plant species, such as Arabidopsis thaliana (33), moss Physicomitrella patens (34), rice (35), and other important crops (36), plant biologists have faced the constant challenge of successfully designating the role and function of each gene as well as their products. They do so in order to complete and improve our understanding of how biological macromolecules interact to shape an organism as a fully functional entity. Due to the extensive number of experimental data from different high-throughput analyses, new terminology has recently been coined. In an attempt to describe a complete dataset of particular biomolecules, two interrelating suffixes were introduced: "-ome" to refer to a particular population of molecules in the cell (e.g., genome, proteome, translatome, metabolome, etc.) and "-omics" to highlight a research interest (such as transcriptomics, proteomics, translatomics, and metabolomics). To obtain deeper insight into the glossary and taxonomy of current "-omes" and "-omics", readers are encouraged to visit the web page of the genomic glossary (37).

The application of modern "-omics" techniques has been useful in expanding our knowledge of molecular pathways involved in the tolerance toward different environmental stresses. Therefore, if we are 
to obtain deeper insight into the plant stress response to biotic or abiotic stresses (38), traditional biochemical and physiological approaches are simply no longer sufficient.

Plant response to abiotic stress, heavy metals included, often occurs as a consequence of changes in protein expression. This response is usually not only accompanied by an alteration in the gene expression pattern, but also by inevitable qualitative and quantitative changes in proteins. Genomic technologies monitor changes at the transcriptional level (i.e., mRNA level), which need not correlate with changes at the translational level (i.e., protein level). Put more simply, a positive correlation would suggest that mRNA transcripts are immediately translated to proteins. According to Anderson and Seilhamer (39), the correlation coefficient in quantity between mRNA and protein abundance is relatively low, approx. 0.5. In reality, the $\mathrm{mRNA} /$ protein ratio depends on both the mRNA translation rate and protein stability (de novo synthesis $v s$. degradation). Moreover, mRNA availability can be affected by post-transcriptional processes at the stage of RNA maturation, splicing, transportation or translation initiation as well as degradation (40). Therefore, the mRNA levels in a particular biological sample cannot always be used to predict changes in protein expression $(30,41)$. In addition, protein expression is also regulated at the posttranslational level via glycosylation, phosphorylation, phosphorylation, sumoylation or ubiquitination $(42,43)$. Proteins, when perceived as the functional translation portion of a genome, play very important roles throughout the plant organism in terms of numerous, structural and functional roles, as well as via effector molecules, in alleviating the stress response induced by internal or environmental stimuli (44). Protein function can also be perceived depending on the level (biochemical, cellular or higher level of biological organization such as organ or whole organism, as well as developmental or physiological) at which a particular protein is studied.

Based on the expanding knowledge on protein function and structure, new technology for their highthroughput analysis has emerged in the form of proteomics. Since proteins are crucial for various cellular processes, proteomics is a promising tool to assess changes in proteins following a variety of stress conditions. Originally, the concept of the proteome was established by Marc Wilkins in the mid-1990s (45) as a combination of the words protein and genome. Widely accepted inside the research community, a proteome is regarded as a complete set of proteins expressed by a genome at a given point in time. More specifically, it represents the entire set of proteins expressed in a specific type of cell or tissue under a specific condition at a specific point of time (46). Proteomics comprises many different aspects of protein roles in the living cell, including the identification and quantification of proteins, patterns of protein expression, posttranslational modification, and protein-protein interactions.

\section{The methodology of proteomics}

Since proteomics is focused on the functional translated portion of the genome, its use is expanding rapidly in the field of heavy metal stress biology. However, proteomic studies of metal stress have been far less numerous and comprehensive in comparison with investigations regarding other environmental stresses in plants (30). Although the processes of heavy metal uptake, accumulation, distribution, oxidative stress induction, and detoxification have been investigated in a wide range of studies on plants (4754 ), the mechanisms involved are still only partially understood. The proteomic approach can therefore help to elucidate new aspects of plant metal stress.

The differential-expression approach in proteomics is used for describing sets of proteomes differing both in protein quality and quantity and is aimed at protein identification and relative quantitative determination. This methodology is most frequently applied in studies dealing with heavy metal stress in plants. It is based on the comparison of the composition of different proteomes, which originate from non-stressed (control) plants and corresponding plants exposed to heavy metals $(24,25,55-67)$. An alternative approach is to compare proteomes from different genotypes with a distinct tolerance for heavy metal stress [e.g., differential responses of proteins in two contrasting Cd-accumulating soybean cultivars $(68,69)$, comparative analysis of proteomic changes in contrasting flax cultivars upon Cd exposure (70), or a comparative proteomic analysis of roots under $\mathrm{Al}$ stress in Al-tolerant and Al-sensitive soybean genotypes (71)].

\section{Protein extraction}

At the present, many studies $(24-26,49,60,62)$ investigating heavy metal toxicity-induced differentially expressed proteins or heavy metal stressresponsive proteins in plants apply a classical gel- 
based proteomic approach, which includes One- (1$\mathrm{DE})$ or Two-Dimensional electrophoresis (2-DE) for a high quality protein separation followed by protein identification via mass spectrometry (MS) analysis and database search (Figure 1).

The extraction of proteins and the preparation of samples is one of the most challenging steps in any proteomics study, particularly in those that comprise 2-DE as their first step. Effective protein extraction, solubilisation, and purification from plant tissues are essential for a good and reproducible 2-DE approach, as the amount and quality of extracted proteins ultimately determine the protein spot number, resolution and intensity. Important characteristics of a good protein isolation method are the reproducible capture and solubilisation of a full set of proteins from a certain sample with minimal post-extraction artefact formation, proteolytic degradation and contamination with non-protein molecules $(72,73)$. In plant proteomics, there are several factors that can affect the method chosen for protein extraction, such as plant species, tissue type, organ, cell, organelle, and the chemical and physical properties of the observed proteins. Generally, in the preparation of protein samples, plants are regarded as "difficult" or recalcitrant tissues due to their low protein content and abundance of cell walls and vacuoles, which account for most of the cell mass (74). Another issue in protein extraction from plant tissues is the presence of phenolic compounds, proteolytic and oxidative enzymes, as well as high levels of polysaccharides, lipids, and other secondary metabolites. These compounds generate horizontal and vertical streaking and smearing and reduce protein resolution on 2-DE gels $(30,75)$. Therefore, in plant protein extraction and solubilisation, the buffer composition with regard to combinations and concentrations of detergents and reducing and chaotropic agents has a considerable effect on the quality of the extracted proteins (76). The most frequently used protocols for the extraction of plant proteins involve a precipitation step, which should serve to separate proteins from interfering compounds originating from a plant's secondary metabolism. Chemicals commonly used for this purpose are acetone, trichloroacetic acid (TCA)/ acetone, and Tris-buffered phenol. A comparison of acetone, TCA/acetone, and phenol extraction methods applied on three plant species, regarded as recalcitrant for 2-DE protein extraction and downstream processing, has shown that phenol extraction was superior to the other two methods, providing more protein bands or spots on the gels and less proteolysis (77). Moreover, a comprehensive proteomic study performed on nine organs from soybean plants in various developmental stages revealed that, whereas the use of an alkaline phosphatase buffer followed by TCA/acetone precipitation caused horizontal streaking in 2-DE, the extraction with alkaline phenol and methanol/ammonium acetate produced high-quality proteome maps with well-separated spots, high spot intensities, and high numbers of separate protein spots in 2-DE gels (78). Sarma et al. (79) also reported a similar preference toward the use of alkaline phenol and methanol/ammonium acetate rather than TCA/ acetone for the extraction of soybean tissues. Some other proteomic studies dealing with plant response to heavy metal stress have confirmed that phenolbased protocols are the most effective protein extraction methods for obtaining a high-quality proteome map $(24,62,68,80-84)$.

The abovementioned extraction procedures are generally used in the separation of soluble proteins by classical proteomic approaches. In the case of organelle proteomics, particularly those that include membrane proteins, a modified extraction procedure should be applied to dissolve hydrophobic proteins and additional purification steps need to be included $(85,86)$. Furthermore, when studying protein-protein interactions, it is necessary to extract protein complexes by using buffers with mild non-denaturing and non-ionic detergents, such as digitonin and dodecyl maltoside, which stabilise protein supercomplexes and allow the dissociation and separation of each protein complex, and therefore, keep proteins in their native states (87).

One of the fundamental challenges in proteome analysis is the fact that samples are often dominated by a relatively small number of high-abundance proteins whose presence can obscure that of the less abundant ones, thus limiting the capacity and resolution of the separation technique(s) employed. Among plant tissues, this problem is very apparent in leaves and other photosynthetic tissues, where the majority of proteins is highly hindered by a single protein, ribulose bisphosphate carboxylase ( $\mathrm{RuBisCo}$ ) (88).Therefore, a group of methodological strategies for the separation of protein molecules for proteomics, called separomics, is applied for the identification of low-abundance proteins and peptides in plants (89). Different techniques have been developed to remove or reduce a substantial portion of RuBisCo from leaf protein extracts, such as the partial removal of 


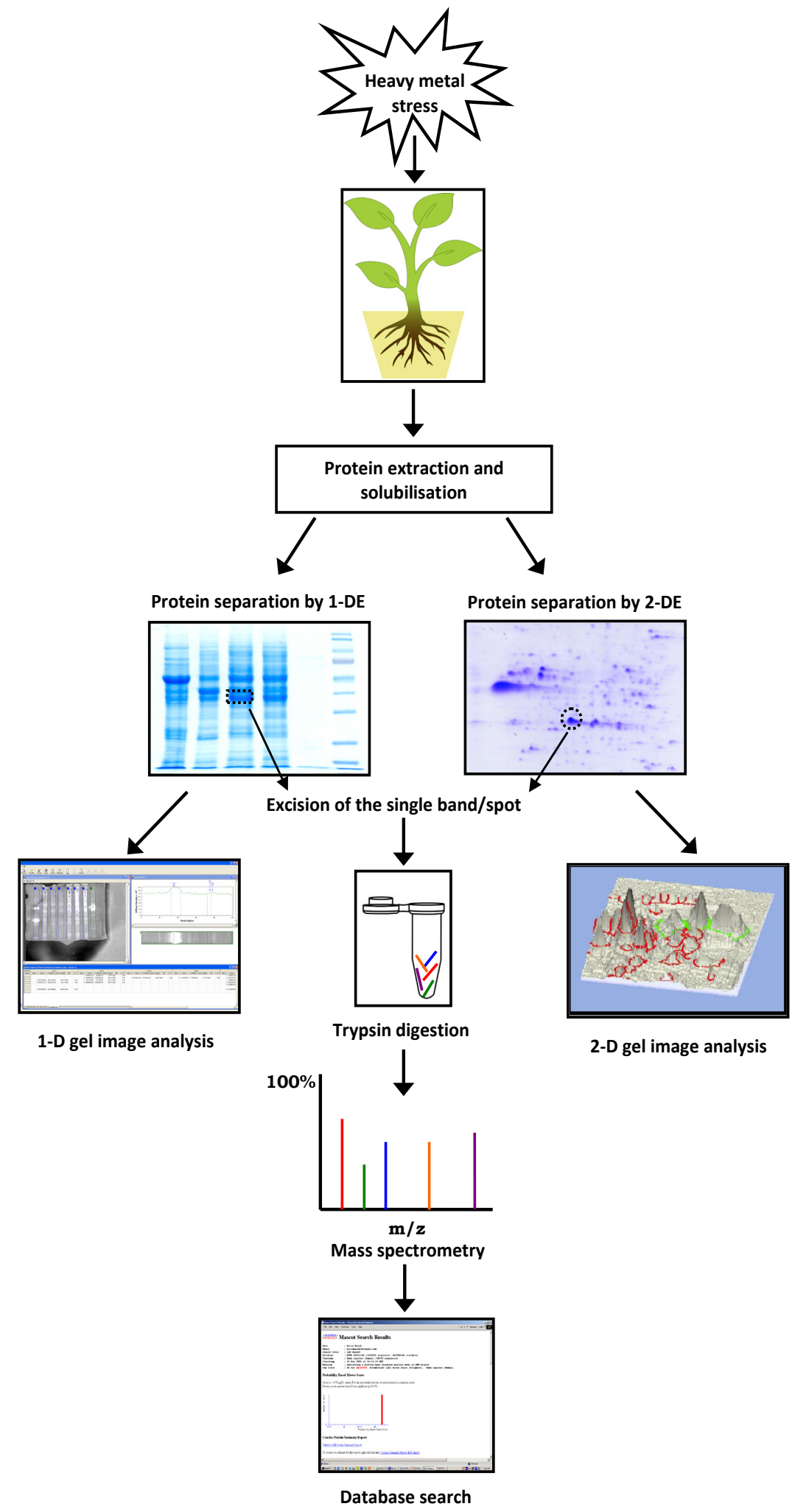

Figure 1 Outline of the gel-based proteomic approach for studying heavy metal stress in plants 
RuBisCo by the increasing dithiothreitol concentration in rice leaves extracts (90), or by applying a fast and simple fractionation technique using $10 \mathrm{mmol} \mathrm{L}^{-1} \mathrm{Ca}^{2+}$ and $10 \mathrm{mmol} \mathrm{L}^{-1}$ phytate to precipitate RuBisCo from soluble protein extracts of soybean leaf (91). Moreover, additional methods have been employed to reduce high-abundance proteins in extracts in order to improve the low-abundance protein detection, such as addition of isopropanol to remove storage proteins from soybean seeds extracts (92), division of the proteome into subproteomes in membranes of banana leaves (93), and the use of affinity and immunoaffinity columns for protein purification $(94,95)$. One particular methodology seems very promising - the use of combinatorial hexapeptide ligand libraries (CPLL; such as ProteoMiner), which have been applied for the detection of low abundance proteins in plant tissues and demonstrated a remarkable decrease in high-abundance proteins as well as an enrichment of less abundant proteins $(96,97)$. The concomitant enrichment of less abundant proteins may facilitate a deeper insight into the plant proteome, which could lead to novel findings of the changes in plant proteins induced by heavy metal stress.

\section{One- and two-dimensional polyacrylamide gel electrophoresis (1- and 2-DE)}

An average protein extract, even from a purified fraction, is a mixture of a large number of individual proteins as well as several other non-protein components. The main goal of the analysis of such a mixture is to acquire as much qualitative and quantitative information on the investigated proteome as possible. One of the most frequently applied approaches is to provide protein separation by means of gel electrophoresis, which is based on the migration of molecules in an electric field in a gel medium. Oneand Two-Dimensional polyacrylamide gel Electrophoresis are common separation methods employed in the analysis of proteins. Both electrophoretic techniques are frequently used to profile cell or tissue proteins or determine the purity of native or recombinant proteins $(98,99)$. OneDimensional Electrophoresis has been successfully applied for the analysis of protein profile of tobacco seedlings and adult plants experimentally exposed to $\mathrm{Cd}$ and $\mathrm{Zn}(100)$ as well as in the study of physiological and proteomic changes in germinating rice seeds induced by $\mathrm{Cu}$ (58). However, 1-DE has a major disadvantage in resolving protein mixtures according to only one physicochemical attribute, mostly molecular weight (MW) (101). Therefore, it is very likely that one protein band obtained on a gel comprises numerous proteins of different characteristics and functions, simply because they all possess a very similar MW. On the other hand, 2-DE represents a much more powerful technique for protein separation since it resolves proteins by two properties (102). In classical gel-based proteomics, proteins are resolved in the first dimension by isoelectric focusing (IEF), which separates proteins according to their charge, i.e. isoelectric point (pI), the $\mathrm{pH}$ at which an amino acid does not migrate in an electric field (103). This is the most critical step of the 2-DE process. There are two alternative methods to create a $\mathrm{pH}$ gradient - carrier ampholytes and immobilized $\mathrm{pH}$ gradient (IPG) gels. When IPGs were introduced for the first dimension, they brought about better resolution and reproducibility in protein separation (104). IPG gels have a dried homogeneous polyacrylamide gel matrix covalently bound to a plastic carrier and are available in several overlapping $\mathrm{pH}$ ranges (narrow-, medium-, and widerange) and different strip lengths. Prior to use, IPG gels are rehydrated with an adequate buffer. Protein samples can be included directly in the rehydration solution for efficient loading of dilute samples or for loading larger amounts of protein. Alternatively, samples can be loaded after rehydration directly on the IPG gels. The second dimension is a classical Sodium Dodecyl Sulphate Polyacrylamide Gel Electrophoresis (SDS-PAGE), which separates proteins according to their MW. Each spot on the resulting 2-D gel corresponds to a single protein in the sample. Thousands of different proteins can be separated and information such as the pI, apparent MW and the amount of each protein can be obtained $(103,104)$.

Methodological advances in 2-DE have led to the development of 2-D Differential In-Gel Electrophoresis (2-D DIGE) (105), a variant of 2-DE that overcomes some of the drawbacks of the original technique, mainly the variation between gels that often leads to multiple repeat runs. It is a high throughput technique that enables several samples to be simultaneously separated and visualized in one gel by labelling proteins with various fluorescent reagents before 2-DE. Different pools of proteins are labelled with different fluorescent dyes (up to three, $\mathrm{Cy} 2, \mathrm{Cy} 3$, or Cy5). The samples are then mixed and resolved on the same 2-D gel. The gel is scanned with the excitation wavelength of each dye one after the other, which allows imaging of each sample separately, or the 
images of all samples can be overlapped to allow better comparison of differentially expressed proteins (106). Cy fluorescence is linear over a wide range of concentrations and sensitive down to $125 \mathrm{pg}$ (105). Accordingly, this method successfully overcomes limitations in traditional 2-DE, considerably reduces gel-to-gel variation, and improves the power of quantitative analyses. Two-Dimensional DIGE also has the advantage of running an internal standard as part of each separation, which allows the measurement of the abundance of a protein in each sample relative to the internal standard. This technique can reveal the presence of several hundred proteins in a highly reproducible manner and remains unchallenged as the most efficient method for analysing complex protein mixtures. So far 2-D DIGE has been used to successfully identify heavy metal-induced differentially regulated proteins in Cd-exposed poplar plants (25), for proteomic analysis of soybean roots under aluminium (Al) stress (71) and to affirm Alinduced proteome changes in tomato cotyledons (67) (Table 1$)$. The results obtained by these studies $(25$, $67,71)$ indicate that 2-D DIGE in combination with MS is a powerful tool for the molecular characterization of plant heavy metal stress and identification of stressspecific protein markers.

For a high resolution separation of enzymatically active protein complexes from tissues and cells, Blue Native Polyacrylamide Gel Electrophoresis (BNPAGE) is the method of choice $(107,108)$. It is a special form of native electrophoresis, which allows separation of proteins between 10 and $10000 \mathrm{kDa}$ (109), and is particularly suitable for separation of membrane protein complexes after their solubilisation with mild neutral detergents. The separation principle relies on binding of dye Coomassie blue G-250, which provides negative charges to the surface of the protein. During migration to the anode, protein complexes are separated according to MW as blue bands. BN-PAGE allows efficient protein resolution under native conditions and therefore proteins keep their activity. BN-PAGE gel strips or individual protein complex bands can be used for different downstream analyses. BN-PAGE in conjunction with denaturing SDS-PAGE can give insights into the protein complex composition and protein-protein interactions as it provides a better separation of high MW protein complexes associated with the proteomes of organelles such as chloroplasts and mitochondria (110).

The principle of the conjunction of these two electrophoretic methods is that protein complexes are separated according to their sizes using BN-PAGE; a BN-PAGE gel strip is denatured and placed on the top of a second dimension SDS-PAGE gel; in the second dimension the protein complexes are separated into their individual subunits. Two-dimensional BN-SDSPAGE (2-D BN-SDS-PAGE) coupled with MS has been used so far to analyse the heavy metal stress responses of multiprotein complexes in the leaf apoplast proteome $(59,111)$ and thylakoid membrane (112) (Table 1), and also permits direct quantitative assessment of differential changes in a given proteome.

\section{Gel image analysis}

Various types of imaging systems and associated software are commercially available for analysing gels stained with any of the commonly used gel stains. ImageQuant TL (GE Healthcare), an automatic and easy-to-use general image analysis software represents a very frequently applied technique, although there are several other programs that can be found on the market like EZQuant-Gel (Microsoft ${ }^{\mathrm{TM}}$ Windows ${ }^{\mathrm{TM}}$ application for analysis of 1-D gels), Quantity One (Bio-Rad), and BioDocAnalyze (Biometra) that are of equally high quality. Apart from these commercially available programs there is also a number of freeware software for 1-D gel electrophoresis image analysis like GelAnalyzer (113) and GelScape (114), which are free for both educational and commercial usage, although specifically designed for educational institutes and researchers. All 1-D gel analysis software has similar characteristics; they can define lanes and bands, quantify bands, create standard curves and determine MW. In all of these programs, images can be adjusted for contrast, processed in various ways, annotated and exported to other files for publication or document control.

The 2-D analysis software assigns and quantifies protein spots in 2-DE gels. Moreover, these programs include statistical software designed for quantitative comparisons of large numbers of gels and are suitable for analysis of spot patterns derived from differentially expressed proteins. Some can be supported by databases to help protein identification. All 2-D analysis software can be used for image adjustments, annotation and export in a variety of file forms. The most prominent among them are ImageMaster 2D Platinum (GE Healthcare), PDQuest (Bio-Rad), REDFIN (Ludesi), Dymension (Syngene), "Progenesis" (Nonlinear Dynamics), and "Proteovue" (Eprogen). Differential labelling with fluorescent dyes Cy2, Cy3 and Cy5 (DIGE technology, GE Healthcare) 
Table 1 Summary of proteomic studies of plant response to heavy metal stress published between 2003 and 2013

\begin{tabular}{|c|c|c|c|c|}
\hline Metal & $\begin{array}{l}\text { Plant species and } \\
\text { tissue }\end{array}$ & $\begin{array}{l}\text { Proteomic } \\
\text { methodology }\end{array}$ & Major findings & Ref. \\
\hline \multirow{12}{*}{ Cd } & $\begin{array}{l}\text { Populus tremula } \mathrm{L} \text {. } \\
\text { leaf, root }\end{array}$ & $\begin{array}{l}\text { IPG, 2-D DIGE, } \\
\text { MALDI-TOF-TOF } \\
\text { MS }\end{array}$ & $\begin{array}{l}\text { Deleterious effect on proteins involved } \\
\text { in the primary carbon metabolism and } \\
\text { oxidative stress response }\end{array}$ & 25 \\
\hline & $\begin{array}{l}\text { Populus tremula L. } \\
\text { leaf }\end{array}$ & $\begin{array}{l}\text { IPG, 2-D DIGE, } \\
\text { MALDI-TOF-TOF } \\
\text { MS }\end{array}$ & $\begin{array}{l}\text { Enhanced accumulation of stress-related } \\
\text { proteins }\end{array}$ & 26 \\
\hline & $\begin{array}{l}\text { Brassica juncea L. (Acc: } \\
\text { PI 173874) } \\
\text { root }\end{array}$ & $\begin{array}{l}\text { IPG, 2-D DIGE, } \\
\text { iTRAQ, nano LC- } \\
\text { MS/MS }\end{array}$ & $\begin{array}{l}\text { Overexpression of sulfite reductase and } \\
\text { O-acetylserine sulfhydrylase, involved in } \\
\text { reduction of sulfate to cysteine }\end{array}$ & 80 \\
\hline & $\begin{array}{l}\text { Hordeum vulgare L. var. } \\
\text { Baraka } \\
\text { leaf mesophyll tonoplast }\end{array}$ & $\begin{array}{l}\text { iTRAQ labelling, } \\
\text { MALDI-TOF-TOF } \\
\text { MS }\end{array}$ & $\begin{array}{l}\text { MRP-like } \mathrm{ABC} \text { transporter and two novel } \\
\mathrm{CAX} \text { transporters (CAX1a and CAX5) } \\
\text { assure } \mathrm{Cd}^{2+} \text { transport into vacuole }\end{array}$ & 130 \\
\hline & $\begin{array}{l}\text { Spinacia oleracea L. } \\
\text { thylakoid membrane }\end{array}$ & $\begin{array}{l}\text { IPG, 2D BN-SDS- } \\
\text { PAGE, nano LC-MS/ } \\
\text { MS }\end{array}$ & $\begin{array}{l}\text { Strong reduction of chlorophyll } \\
\text { concentration; significant reduction } \\
\text { of antenna proteins of PSI, while PSII } \\
\text { antennae were affected to a minor extent }\end{array}$ & 112 \\
\hline & $\begin{array}{l}\text { Oryza sativa L. cv. } \\
\text { Dongjin } \\
\text { leaf, root }\end{array}$ & $\begin{array}{l}\text { IPG, 2-DE, MALDI- } \\
\text { TOF MS }\end{array}$ & $\begin{array}{l}\text { Activation and up-regulation of ROS } \\
\text { scavengers }\end{array}$ & 62 \\
\hline & $\begin{array}{l}\text { Lycopersicon esculentum } \\
\text { Mill cv. Tres Cantos } \\
\text { root }\end{array}$ & $\begin{array}{l}\text { IPG, 2-DE, MALDI- } \\
\text { TOF MS, LIFT TOF- } \\
\text { TOF }\end{array}$ & $\begin{array}{l}\text { Up-regulation of Hsp } 70 \text { and higher } \\
\text { abundance of glycolytic and TCA cycle } \\
\text { enzymes }\end{array}$ & 83 \\
\hline & $\begin{array}{l}\text { Linum usitatissimum L. } \\
\text { cv. Jitka, cv. Tábor } \\
\text { cell suspension culture }\end{array}$ & $\begin{array}{l}\text { IPG, 2-DE, MALDI- } \\
\text { TOF MS }\end{array}$ & $\begin{array}{l}\text { Up-regulation of proteins associated with } \\
\text { Cd-chelating pathways }\end{array}$ & 70 \\
\hline & $\begin{array}{l}\text { Arabidopsis thaliana } \\
\text { ecotype Columbia } \\
\text { seedlings (aerial parts) }\end{array}$ & $\begin{array}{l}\text { IPG, 2-DE, LC-ESI- } \\
\text { MS/MS }\end{array}$ & $\begin{array}{l}\text { Up-regulation of proteins associated with } \\
\text { Cd-chelating pathways }\end{array}$ & 66 \\
\hline & $\begin{array}{l}\text { Glycine } \max \text { L. cv. Enrei, } \\
\text { Harosoy } \\
\text { root microsome }\end{array}$ & $\begin{array}{l}\text { IPG, 2-DE, nano LC- } \\
\text { MS/MS }\end{array}$ & $\begin{array}{l}\text { Up-regulation of proteins associated with } \\
\text { Cd-chelating pathways }\end{array}$ & 68 \\
\hline & $\begin{array}{l}\text { Glycine max L. cv. Enrei, } \\
\text { Harosoy, Fukuyutaka, } \\
\text { CDH- } 80 \\
\text { leaf, root }\end{array}$ & $\begin{array}{l}\text { IPG, 2-DE, nano LC- } \\
\text { MS/MS, MALDI- } \\
\text { TOF MS }\end{array}$ & $\begin{array}{l}\text { Activation and up-regulation of ROS } \\
\text { scavengers accumulation of molecular } \\
\text { chaperons and heat-shock proteins }\end{array}$ & 61 \\
\hline & $\begin{array}{l}\text { Glycine } \max \text { L. cv. Enrei } \\
\text { leaf }\end{array}$ & $\begin{array}{l}\text { IPG, 2-DE, nano LC- } \\
\text { MS/MS, MALDI- } \\
\text { TOF MS }\end{array}$ & Abundance of Hsp70 and Peroxiredoxin & 69 \\
\hline \multirow{5}{*}{$\mathrm{Cu}$} & $\begin{array}{l}\text { Cannabis sativa var. } \\
\text { Felina } 34 \\
\text { root }\end{array}$ & $\begin{array}{l}\text { IPG, 2-DE, LC-MS/ } \\
\text { MS }\end{array}$ & $\begin{array}{l}\text { Down-regulation of glycolytic enzyme } \\
\text { ENO, the metallo enzyme that catalyses } \\
\text { conversion of 2-phosphoglycerate to } \\
\text { phosphoenolpyruvate }\end{array}$ & 24 \\
\hline & $\begin{array}{l}\text { Oryza sativa L. cv. } \\
\text { Hwayeong } \\
\text { germinating seeds }\end{array}$ & $\begin{array}{l}\text { 1-DE, IEF tube gel, } \\
\text { 2-DE, MALDI-TOF } \\
\text { MS }\end{array}$ & $\begin{array}{l}\text { Accumulation of antioxidant and stress- } \\
\text { related proteins }\end{array}$ & 58 \\
\hline & $\begin{array}{l}\text { Oryza sativa } \mathrm{L} \text {. } \\
\text { Wuyunjing } \\
\text { germinating embryos }\end{array}$ & $\begin{array}{l}\text { IPG, 2-DE, MALDI- } \\
\text { TOF MS }\end{array}$ & $\begin{array}{l}\text { Increased abundance of PR-10a and } \\
\text { putative PR proteins as well as of GSTs; } \\
\text { down-regulation of Trx and Trx-POD }\end{array}$ & 116 \\
\hline & $\begin{array}{l}\text { Elsholtzia splendens L. } \\
\text { leaf, root }\end{array}$ & $\begin{array}{l}\text { IPG, 2-DE, MALDI- } \\
\text { TOF MS, LTQ-ESI- } \\
\text { MS/MS }\end{array}$ & $\begin{array}{l}\text { Up-regulation of proteins with potential } \\
\text { ion-binding functions and proteins engaged } \\
\text { in vacuolar metal sequestrations }\end{array}$ & 115 \\
\hline & $\begin{array}{l}\text { Ectocarpus siliculosus } \\
\text { strains Es } 32, \text { Es } 524 \\
\text { algal cells }\end{array}$ & $\begin{array}{l}\text { IPG, 2-DE, MALDI- } \\
\text { TOF MS }\end{array}$ & $\begin{array}{l}\text { Up-regulation of photosynthesis, glycolysis, } \\
\text { and pentose phosphate metabolism }\end{array}$ & 82 \\
\hline
\end{tabular}


Table 1 Continued

\begin{tabular}{|c|c|c|c|c|}
\hline Metal & Plant species and tissue & $\begin{array}{l}\text { Proteomic } \\
\text { methodology }\end{array}$ & Major findings & Ref. \\
\hline \multirow{4}{*}{ As } & $\begin{array}{l}\text { Oryza sativa L. } \\
\text { cv.Dongjin } \\
\text { root }\end{array}$ & $\begin{array}{l}\text { IPG, 2-DE, MALDI- } \\
\text { TOF MS }\end{array}$ & $\begin{array}{l}\text { Enhanced expression of antioxidative } \\
\text { enzymes }\end{array}$ & 56 \\
\hline & $\begin{array}{l}\text { Agrostis tenuis L. } \\
\text { leaf }\end{array}$ & $\begin{array}{l}\text { IPG, 2-DE, MALDI- } \\
\text { TOF MS }\end{array}$ & $\begin{array}{l}\text { Degradation of several protein involved } \\
\text { in photosynthesis, RuBisCo in particular }\end{array}$ & 117 \\
\hline & $\begin{array}{l}\text { Oryza sativa L. } \\
\text { cv.Dongjin } \\
\text { leaf }\end{array}$ & $\begin{array}{l}\text { IPG, 2-DE, MALDI- } \\
\text { TOF MS, ESI-MS/MS }\end{array}$ & $\begin{array}{l}\text { Over-expression of energy and } \\
\text { metabolism related proteins }\end{array}$ & 55 \\
\hline & $\begin{array}{l}\text { Anabaena sp. PCC } 7120 \\
\text { algal cells }\end{array}$ & $\begin{array}{l}\text { PG, 2-DE, MALDI- } \\
\text { TOF MS, LC-MS }\end{array}$ & $\begin{array}{l}\text { Over-expression of energy and } \\
\text { metabolism related proteins }\end{array}$ & 63 \\
\hline \multirow{4}{*}{ Al } & $\begin{array}{l}\text { Glycine } \max (\mathrm{L} .) \text { Merr } \\
\text { cvs. BaXi 10, BenDi } 2 \\
\text { root }\end{array}$ & $\begin{array}{l}\text { IPG, 2-DE, MALDI- } \\
\text { TOF MS }\end{array}$ & $\begin{array}{l}\text { CS and GSH play essential role in } \mathrm{Al} \\
\text { adaptation; activation of molecular } \\
\text { chaperons }\end{array}$ & 118 \\
\hline & $\begin{array}{l}\text { Oryza sativa } \mathrm{L} . \mathrm{cv} . \\
\text { Xiangnuo } 1(\mathrm{XN} 1) \\
\text { root }\end{array}$ & $\begin{array}{l}\text { IPG, 2-DE, MALDI- } \\
\text { TOF MS, MALDI- } \\
\text { TOF/TOF MS }\end{array}$ & $\begin{array}{l}\text { CS and GSH play essential role in Al } \\
\text { adaptation; enhanced accumulation } \\
\text { of several enzymes involved in ROS } \\
\text { detoxification }\end{array}$ & 119 \\
\hline & $\begin{array}{l}\text { Solanum esculentum Mill } \\
\text { cv. Money Maker } \\
\text { root }\end{array}$ & $\begin{array}{l}\text { IPG, 2-DE, MALDI- } \\
\text { TOF/TOF MS }\end{array}$ & $\begin{array}{l}\text { Induced enzymes with antioxidant } \\
\text { activities and detoxification }\end{array}$ & 67 \\
\hline & $\begin{array}{l}\text { Glycine } \max (\mathrm{L} .) \\
\text { genotypes PI } 416937 \text { and } \\
\text { Young } \\
\text { root }\end{array}$ & $\begin{array}{l}\text { IPG, 2-D DIGE, } \\
\text { MALDI-TOF MS, } \\
\text { MALDI-TOF/TOF MS }\end{array}$ & $\begin{array}{l}\text { Tolerant genotype - accumulation of } \\
\text { enzymes which catalyse synthesis of } \\
\text { citrate, involved in } \mathrm{Al}^{3+} \text { detoxification; } \\
\text { sensitive genotype - induction of } \\
\text { proteins related to general stress } \\
\text { response }\end{array}$ & 71 \\
\hline \multirow{3}{*}{ Mn } & $\begin{array}{l}\text { Vigna unguiculata }[\mathrm{L} .] \\
\text { Walp. Cvs TVu 91, TVu } \\
1987 \\
\text { leaf apoplast }\end{array}$ & $\begin{array}{l}\text { IPG, 2-DE, 2D BN- } \\
\text { SDS-PAGE, nano LC- } \\
\text { MS/MS }\end{array}$ & $\begin{array}{l}\text { Role of PODs in the expression of } \mathrm{Mn}^{2+} \\
\text { toxicity mediating } \mathrm{H}_{2} \mathrm{O}_{2} \text { production/ } \\
\text { consumption and the oxidation of } \\
\text { phenols }\end{array}$ & 59 \\
\hline & $\begin{array}{l}\text { Vigna unguiculata }[\mathrm{L} .] \\
\text { Walp. Cvs TVu } 91, \mathrm{TVu} \\
1987 \\
\text { leaf symplast }\end{array}$ & $\begin{array}{l}\text { IPG, 2-DE, nano LC- } \\
\text { MS/MS, ESI-MS/MS }\end{array}$ & $\begin{array}{l}\text { Down-regulation of chloroplastic } \\
\text { proteins involved in photosynthesis and } \\
\text { carbon assimilation }\end{array}$ & 60 \\
\hline & $\begin{array}{l}\text { Oryza sativa L. var. } \\
\text { Guara, } \\
\text { Hordeum vulgare L. var. } \\
\text { Baroness } \\
\text { leaf apoplast }\end{array}$ & $\begin{array}{l}\text { IPG, 2-DE, 2D BN- } \\
\text { SDS-PAGE, ESI-MS/ } \\
\text { MS }\end{array}$ & $\begin{array}{l}\text { Mn toxicity in barley involves } \\
\text { apoplastic lesions mediated by PODs; } \\
\text { lower Mn tolerance of young rice leaves } \\
\text { in comparison to old ones }\end{array}$ & 111 \\
\hline \multirow{3}{*}{$\mathrm{Cr}$} & $\begin{array}{l}\text { Pseudokirchneriella } \\
\text { subcapitata } \text { strain Hindák } \\
\text { algal cells }\end{array}$ & $\begin{array}{l}\text { IPG, 2-DE, LC-ESI- } \\
\text { MS/MS }\end{array}$ & $\begin{array}{l}\text { Enhanced abundance of RuBisCo } \\
\text { activase and modulation of proteins } \\
\text { involved in amino acids metabolism }\end{array}$ & 81 \\
\hline & $\begin{array}{l}\text { Miscanthus sinensis cv. } \\
\text { Kosung } \\
\text { root }\end{array}$ & $\begin{array}{l}\text { IPG, 2-DE, MALDI- } \\
\text { TOF MS, MALDI- } \\
\text { TOF/TOF MS }\end{array}$ & $\begin{array}{l}\text { Accumulation of Cr-responsive proteins } \\
\text { linked to heavy metal tolerance and } \\
\text { senescence pathways }\end{array}$ & 84 \\
\hline & $\begin{array}{l}\text { Zea mays L.cv. Zheng } 58 \\
\text { leaf }\end{array}$ & $\begin{array}{l}\text { IPG, 2-DE, MALDI- } \\
\text { TOF/TOF MS }\end{array}$ & $\begin{array}{l}\text { Enhanced expression of proteins } \\
\text { involved in ROS detoxification, } \\
\text { defense responses, photosynthesis, and } \\
\text { chloroplast organization }\end{array}$ & 120 \\
\hline \multirow[t]{2}{*}{ B } & $\begin{array}{l}\text { Hordeum vulgare cvs. GP, } \\
\text { Cp, Sh, Cp x Sh DH } \\
\text { leaf, root }\end{array}$ & $\begin{array}{l}\text { iTRAQ peptide tagging, } \\
\text { MS/MS }\end{array}$ & $\begin{array}{l}\text { Enhanced abundance of enzymes } \\
\text { involved in production of proteins } \\
\text { with a strong chelating activity, } \\
\text { phytosiderophores, which participate in } \\
\text { iron up-take in B-tolerant barley }\end{array}$ & 129 \\
\hline & $\begin{array}{l}\text { Lupinus albus cv. Rio } \\
\text { Maior } \\
\text { root }\end{array}$ & IPG, 2-DE, LC-MS/MS & $\begin{array}{l}\text { Under B deficiency proteins involved } \\
\text { in energy, cell division, and protein } \\
\text { metabolic processes were down- } \\
\text { regulated }\end{array}$ & 121 \\
\hline
\end{tabular}


greatly improves comparisons between samples for which the DeCyder 2D Differential Analysis Software was developed.

\section{Mass spectrometry (MS) techniques}

In any proteome analysis, a number of proteins is separated. This approach typically comprises 2-DE coupled with MS techniques such as Matrix-Assisted Laser Desorption Ionization Time-of-Flight (MALDITOF) MS or nanoscale liquid chromatography (nanoLC) electrospray ionization (ESI)-MS/MS analysis (38). The first step is usually 2-DE, as previously described. The protein spots obtained are excised from the gel and submerged to digestion with an appropriate protease, most frequently trypsin, to obtain a mixture of peptides. In the following step, a peptide map called "peptide mass fingerprint" is constructed by MS in order to identify the protein. Alternatively, the partial amino acid sequence is determined by "de novo sequencing" and occasionally by a gas-phase protein sequencer. Then the database constructed by the genome analysis is retrieved and the gene corresponding to the protein of interest can be identified. The entry of the protein sequence database shows which proteins have been assigned particular functions. If the sequence of the analysed protein is identical or similar to other proteins from the database with a known function, the function of the target protein can be identified. This approach has been successfully applied in proteomic studies of different plant species exposed to $\mathrm{Cd}(25,26,61,62,66,68-70,80,83,112), \mathrm{Cu}(24$, $82,115,116)$, As $(55,56,63,117), \operatorname{Al}(67,71,118$, $119), \operatorname{Mn}(59,60,111), \mathrm{Cr}(81,84,120)$, and B (121) (Table 1).

Although classical proteomic approaches can identify several hundred heavy metal-responsive proteins from plant samples, they are still not apt for resolving and identifying certain components of protein complexes composed of multiple subunits. A number of second-generation gel-free MS-based proteomic technologies have been developed that can be implemented not only for protein identification, but also for determination of protein quantity. Techniques such as stable isotope labelling of amino acids in cell culture (SILAC), isotope tagging for relative and absolute protein quantitation (iTRAQ), and intensitybased absolute quantitation (BAQ) can be applied for identifying almost all types of proteins, including highly acidic, basic, and hydrophobic proteins, as well as protein complexes (122-124). SILAC is a simple and straightforward approach for the in vivo incorporation of a label into proteins for MS-based quantitative proteomics and it relies on metabolic incorporation of a given 'light' or 'heavy' form of the amino acid with substituted stable isotopic nuclei (e.g., deuterium, ${ }^{13} \mathrm{C},{ }^{15} \mathrm{~N}$ ) into proteins. Differential labelling of plant cells by two different versions of the labelled amino acids enables similar quantitation accuracy, precision, and reproducibility as conventional SILAC in animal cells (125). The iTRAQ method is based on isobaric tags, i.e. tags that have the same mass and are primarily designed for chemically labelling the N-terminus of peptides generated from protein digests that have been isolated from cells exposed to, for example, two different environmental conditions. The labelled samples are combined, fractionated by nano LC and analysed by tandem mass spectrometry. Database searches for peptide fragmentation data result in the identification of labelled peptides and corresponding proteins (126). iBAQ is a label-free proteome quantification method which is applicable for an accurate calculation of protein concentrations at the proteome level (127). iBAQ has proven to be suitable for proteomics-based identification of low-abundance signalling and regulatory protein complexes in native plant tissues (124). Currently, SILAC, iTRAQ, and iBAQ are considered to be among the most promising techniques for large-scale quantitative proteome analyses in plant biology $(128,124)$. However, despite numerous advantages of quantitative shotgun proteomics, there are only a few reports that employed these techniques for analyses of metal toxicity-induced proteins in plants $(80,129,130)$. iTRAQ was used by Patterson et al. (129) for quantitative determination of proteins in two barley cultivars with different sensitivity to increased boron concentrations and the results obtained suggested that iTRAQ had a considerable potential for identifying and quantifying the expression of proteins in conjunction with bulked segregant analysis. Schneider et al. (130) applied the same technique to elucidate the role of vacuolar transporters in Cd-detoxification processes in the proteome of barley leaf tonoplast. Comparative proteomic approaches, including both gel-based (2D-DIGE) and gel-free (iTRAQ) techniques were applied by Alvarez et al. (80) to investigate the response of Brassica juncea roots to $\mathrm{Cd}$ treatment. They found that membrane and low abundant proteins were primarily identified by the iTRAQ method, while 2D-DIGE analysis identified many differentially expressed posttranslationally modified proteins, suggesting that 
each method has its own advantages and the best approach would be to apply them both in a complementary manner. However, Finka and Golubinoff (131) managed to demonstrate a robust protocol for the normalisation of $\mathrm{BAAQ}$ data for the purpose of analysing protein stoichiometries in complexes.

\section{Current trends in proteomics of heavy metal toxicity in plants}

In recent years, due to the advancement in techniques involving the identification and separation of proteins, substantial effort has been made in the clarification of molecular mechanisms underlying heavy metals toxicity in plants, but the importance of protein profiling has still not waned. The number of proteomic studies that have been carried out under different stress conditions in plants is relatively low, but for heavy metals-induced stress, proteomics studies are considerably even less represented (19, $38)$.

The greatest number of proteomic studies dealing with adverse effects of heavy metals on a proteome of different plant species has focused on the impact of $\mathrm{Cd}$ exposure. In a proteomic study on Cd-stressed poplar plants (25), it was found that this heavy metal had a deleterious effect on the expression of proteins involved in the primary carbon metabolism and from the oxidative stress response of stem tissue. Moreover, leaf and root proteome of poplar plants exposed to $\mathrm{Cd}^{2+}$ exhibited both an enhanced accumulation of stress-related proteins, like heat shock proteins, chaperones, foldases, proteases and pathogenesisrelated (PR) proteins, while for the root tissue significant decrease in most proteins from the primary metabolism was characteristic (26). Several papers reported an activation and up-regulation of ROS scavengers, thus indicating a prompt antioxidative response to oxidative stress damage induced by $\mathrm{Cd}$ $(61,62,69) . \mathrm{Cd}^{2+}$ also induced an enhanced accumulation of proteins such as molecular chaperons (61) and heat-shock proteins (69), which are protective proteins that contribute to protein stabilisation, adequate folding, assembly, and translocation under both optimal and stressed growth conditions (132). In many studies, up-regulation of proteins associated with Cd-chelating pathways was reported $(25,49,66$, 68,70 ). In order to cope with an excess of heavy metals, plants have developed effective mechanism to synthesize chelators of low molecular weight in order to minimize the binding of toxic metal ions to functionally important proteins (133).

Exposure to $\mathrm{Cu}$ mostly resulted in the up-regulation of photosynthesis, glycolysis, and pentose phosphate metabolism (82) as well as in enhanced accumulation of antioxidant and stress-related proteins (58). Moreover, Li et al. (115) examined the effects of increased $\mathrm{Cu}$ concentrations on Elsholtzia splendens and found that expression of several proteins with potential ion-binding functions as well as proteins engaged in vacuolar metal sequestrations were upregulated.

Increased concentrations of arsenite or arsenate induced the over-expression of energy and metabolism related proteins $(55,63)$ and enhanced the expression of antioxidative enzymes (56), which indicated a higher energy demand and induced oxidative stress during As exposure. In addition, elevated As content led to a partial disruption of photosynthetic processes and degradation of several proteins involved in photosynthesis, RuBisCO in particular (117).

In studies of $\mathrm{Al}^{3+}$ toxicity it was found that cysteine synthase (CS) and glutathione (GSH) play an essential role in the $\mathrm{Al}$ adaptation of soybean (118) and rice (119). Moreover, it was also reported that Al-exposure induced activation of molecular chaperons in soybean (118), while an enhanced accumulation of several enzymes involved in ROS detoxification was found in rice roots (119). Proteomic analysis on tomato root tissue has shown that $\mathrm{Al}$ treatment induced enzymes associated with antioxidant activities and detoxification (67). Comparative analysis of root proteome of aluminium-tolerant and aluminium-sensitive soybean genotypes revealed an enhanced accumulation of enzymes that catalyse the synthesis of citrate, a key organic acid involved in $\mathrm{Al}^{3+}$ detoxification in a tolerant genotype, while proteins related to general stress response were induced in sensitive soybean (71).

Effects of increased manganese concentrations were investigated in legume crop cowpea (Vigna unguiculata) leaf apoplast (59) and symplast (60). Fecht-Christoffers et al. (59) revealed the particular role of peroxidases (PODs) in the expression of $\mathrm{Mn}^{2+}$ toxicity mediating $\mathrm{H}_{2} \mathrm{O}_{2}$ production/consumption and the oxidation of phenols in the leaf apoplast. The release of PODs in the apoplast was accompanied by the secretion of wound-induced proteins and PR enzymes, e.g. glucanase, chitinase, and thaumatin-like proteins, which appeared to be a late response to excess Mn. Furthermore, Führs et al. (60) reported the down-regulation of chloroplastic proteins involved in 
photosynthesis and carbon assimilation in symplast of cowpea exposed to Mn-stress. A comparative proteomic study of Mn-response in rice and barley suggested that Mn toxicity in barley involved apoplastic lesions mediated by PODs, while the lower $\mathrm{Mn}$ tolerance of young rice leaves in comparison to old ones could have beeen related to Mn excessinduced displacement of $\mathrm{Mg}$ and $\mathrm{Fe}$ from essential metabolic functions (111).

Under chromate treatment of Pseudokirchneriella subcapitata, an enhanced abundance of RuBisCO activase and modulation of proteins involved in amino acids metabolism was reported (81). Moreover, Sharmin et al (84) found novel accumulation of $\mathrm{Cr}$ responsive proteins linked to heavy metal tolerance and senescence pathways in roots of Miscanthus sinensis. In the study of induced proteomic changes in maize leaf upon $\mathrm{Cr}$ treatment the proteins identified were mainly involved in ROS detoxification and defence responses as well as in photosynthesis and chloroplast organization, which indicates that plants modify their metabolism by an altered expression of genes to adapt to Cr stress (120).

In studies dealing with the influence of boron (B) on plant proteome it was found that proteins involved in energy, cell division, and protein metabolic processes were down-regulated under B deficiency (121). In a comparative proteomic study of B-sensitive and B-tolerant barley exposed to increased B concentrations, Patterson et al (129) reported an enhanced abundance of enzymes phytosiderophores involved in production of proteins with a strong chelatin activity, which participate in iron uptake in B-tolerant barley.

\section{Obstacles and future perspectives}

What still remains challenging in this field is the implementation of proteomic studies in non-model plant species, i.e. plants for which the whole genome sequence is not fully available. For instance, plant scientists are interested in many different species as study objects, because some biological, as well as physiological processes of a particular research interest might not naturally be inherent to traditional model plants $(134,135)$. Nevertheless, high proteome coverage in terms of complete proteome profile lacks information even for model plants (136). Further, the identification of proteins in a particular biological sample does not automatically reveal the protein function. Moreover, proteomics studies have come up with a high number of unknown or hypothetical proteins, up to $50 \%$ of all protein sequences in databases (137). This seems to be even more complex in non-model species for which functional annotation of genes and proteins are at very beginnings (135). However, substantial progress has been made in this field and the results obtained from studies carried out in the last decade have greatly improved our understanding of plant response to heavy metal stress. In the future, proteomic studies of heavy metal stress in plants could pave the way for identifying novel protein candidates that could be used for improving stress tolerance. There is great potential in combining mass spectrometry with Nanostring technology used to quantify particular mRNA, as well as to improve current knowledge of translatomics and transcriptomics in order to get more information of how plant proteins respond to heavy metal stress. Moreover, new findings could be implemented in the engineering of transgenic plants that could be used for phytomining or phytoremediation of heavy metals from contaminated soils $(17,138,139)$.

\section{REFERENCES}

1. Gornall J, Betts R, Burke E, Clark R, Camp J, Willet K, Wiltshire A. Implications of climate change for agricultural productivity in the early twenty-first century. Phil. Trans R Soc B 2010;365:2973-89. doi: 10.1098/rstb.2010.0158

2. Alexandrov V, Eitzinger J, Cajic V, Oberforster M. Potential impact of climate change on selected agricultural crops in north-eastern Austria. Global Change Biol 2002;8:372-89. doi: 10.1046/j.1354-1013.2002.00484.x

3. Mittler R, Finka A, Goloubinoff P. How do plants feel the heat? Trends Biochem Sci 2012;37:118-25. doi: 10.1016/j. tibs.2011.11.007.

4. Nriagu JO, Pacyna JM. Quantitative assessment of worldwide contamination of air, water and soils by trace metals. Nature 1988;333:134-9. doi: 10.1038/333134a0

5. Woolson EA, Axley JH, Kearney PC. The chemistry and phytotoxicity of arsenic in soils: I. Contaminated field soils. Soil Sci Soc Am J 1971;35:938-43.

6. Meharg AA, Rahman M. Arsenic contamination of Bangladesh paddy field soils: implications for rice contribution to arsenic consumption. Environ Sci Technol 2003;37:229-34. doi: 10.1021/es0259842

7. Camargo JA, Ward JV. Short-term toxicity of sodium nitrate $\left(\mathrm{NaNO}_{3}\right)$ to non-target freshwater invertebrates. Chemosphere 1992;24:23-8. doi: 10.1016/0045-6535(92)90563-7

8. Tilman D. Global environmental impacts of agricultural expansion: The need for sustainable and efficient practices. Proc Natl Acad Sci USA 1999;96:5995-6000. doi: 10.1073/ pnas.96.11.5995

9. Kassir LN, Lartiges B, Ouaini N. Effects of fertilizer industry emissions on local soil contamination: a case study of a phosphate plant on the east Mediterranean coast. Environ 
Technol $2012 ; 33: 873-85$ d o i : $10.1080 / 09593330.2011 .601765$

10. Nicholson FA, Smith SR, Alloway BJ, Carlton-Smith C, Chambers BJ. An inventory of heavy metals inputs to agricultural soils in England and Wales. Sci Total Environ 2003;311:205-19. doi: 10.1016/S0048-9697(03)00139-6

11. Satarug S, Baker JR, Urbenjapol S, Haswell-Elkins M, Reilly PEB, Williams DJ. A global perspective on cadmium pollution and toxicity in non-occupationally exposed population. Toxicol Lett 2003;137:65-83. PMID: 12505433

12. Di Toopi LS, Gabrielli R. Response to cadmium in higher plants. Environ Exp Bot 1999;41:105-30.

13. Siedlecka A. Some aspects of interactions between heavy metals and plant mineral nutrients. Acta Soc Bot Pol 1995;64:265-72.

14. Hänsch R, Mendel RR. Physiological functions of mineral micronutrients $(\mathrm{Cu}, \mathrm{Zn}, \mathrm{Mn}, \mathrm{Fe}, \mathrm{Ni}, \mathrm{Mo}, \mathrm{B}, \mathrm{Cl})$. Curr Opin Plant Biol 2009;12:259-66. doi: 10.1016/j.pbi.2009.05.006

15. Saidi Y, Finka A, Goloubinoff P. Heat perception and signalling. Response to cadmium in plants: a tortuous path to thermotolerance. New Phytol 2011;190:556-65.

16. Salt DE, Smith RD, Raskin I. Phytoremediation. Annu Rev Plant Physiol Plant Mol Biol 1998;49:643-68. PMID: 15012249

17. Rugh CL, Senecoff JF, Meagher RB, Merkle SA. Development of transgenic yellow poplar for mercury phytoremediation. Nature Biotechnol 1998;16:925-8. doi: 10.1038/nbt1098-925

18. Jung MC, Thorton I. Heavy metal contamination of soils and plants in the vicinity of a lead-zinc mine, Korea. Appl Geochem 1996;11:53-9. doi: 10.1016/0883-2927(95)00075-5

19. Liao XY, Chen TB, Xie H, Liu YR. Soil As contamination and its risk assessment in areas near the industrial districts of Chenzhou City, Southern China. Environ Int 2005;31:7918. PMID: 15979720

20. Schützendübel A, Polle A. Plant responses to abiotic stresses: heavy metal - induced oxidative stress and protection by mycorrhization. J Exp Bot 2002;53:1351-65. doi: 10.1093/ jexbot/53.372.1351

21. Clemens S. Toxic metal accumulation, responses to exposure and mechanisms of tolerance in plants. Biochimie 2006;88:1707-19. doi: 10.1016/j.biochi.2006.07.003

22. Rogers S, Girolami M, Kolch W, Waters KM, Liu T, Thrall $\mathrm{B}$, Wiley HS. Investigating the correspondence between transcriptomic and proteomic expression profiles using coupled cluster models. Bioinformatics 2008;24:2894-900. 10.1093/bioinformatics/btn553

23. Krämer U, Clemens S. Molecular biology of metal homeostasis and detoxification. In: Tamäs M, Martinoia E, editors. Topics in current genetics. New York (NY): Springer Verlag; 2005. p. 216-71

24. Bona E, Marsano F, Cavaletto M, Berta G. Proteomic characterization of copper stress response in Cannabis sativa roots. Proteomics 2007;7:1121-30. doi: 10.1002/ pmic.200600712

25. Kieffer P, Dommes J, Hoffmann L, Hausman JF, Renaut J. Quantitative changes in protein expression of cadmiumexposed poplar plants. Proteomics 2008;8:2514-30. doi: 10.1002/pmic. 200701110

26. Kieffer P, Planchon S, Oufir M, Ziebel J, Dommes J, Hoffmann L. Combining proteomics and metabolite analyses to unravel cadmium stress-response in poplar leaves. J Proteome Res 2009;8:400-17. doi: 10.1021/pr800561r
27. Giordano PM, Mortvedt J, Mays A. Effect of municipal wastes on crop yields and uptake of heavy metals. J Environ Qua 1 1975;4:394-9. doi: 10.2134/ jeq1975.00472425000400030024x

28. Islam E, Yang X, He Z, Mahmood Q. Assessing potential dietary toxicity of heavy metals in selected vegetables and food crops. J Zhejiang Univ Sci B 2007;8:1-13. doi: 10.1631/ jzus.2007.B0001

29. Fu J, Zhou Q, Liu J, Liu W, Wang T, Zhang Q, Jiang G. High levels of heavy metals in rice (Oryza sativa L.) from a typical E-waste recycling area in southeast China and its potential risk to human health. Chemosphere 2008;71:1269-75. doi: 10.1016/j.chemosphere.2007.11.065

30. Hossain Z, Komatsu S. Contribution of proteomic studies towards understanding plant heavy metal stress response. Front Plant Sci 2013;3:310. doi: 10.3389/fpls.2012.00310

31. Clemens S. Molecular mechanisms of plant metal tolerance and homeostasis. Planta 2001;212:475-86. PMID: 11525504

32. Sharma SK, Goloubinoff $P$, Christen P. Heavy metal ions are potent inhibitors of protein folding. Biochem Biophys Res Commun 2008;372:341-5. doi: 10.1016/j.bbrc.2008.05.052

33. The Arabidopsis Genome Initiative. Analysis of the genome sequence of the flowering plant Arabidopsis thaliana. Nature 2000;408:796-815. doi: 10.1038/35048692

34. Rensing SA, Lang D, Zimmer AD, Terry A, Salamov A, Shapiro H, Nishiyama T, Perroud PF, Lindquist EA, Kamisugi Y, Tanahashi T, Sakakibara K, Fujita T, Oishi K, Shin-I T, Kuroki Y, Toyoda A, Suzuki Y, Hashimoto S, Yamaguchi K, Sugano S, Kohara Y, Fujiyama A, Anterola A, Aoki S, Ashton N, Barbazuk WB, Barker E, Bennetzen JL, Blankenship R, Cho SH, Dutcher SK, Estelle M, Fawcett JA, Gundlach H, Hanada K, Heyl A, Hicks KA, Hughes J, Lohr M, Mayer K, Melkozernov A, Murata T, Nelson DR, Pils B, Prigge M, Reiss B, Renner T, Rombauts S, Rushton PJ, Sanderfoot A, Schween G, Shiu SH, Stueber K, Theodoulou FL, Tu H, Van de Peer Y, Verrier PJ, Waters E, Wood A, Yang L, Cove D, Cuming AC, Hasebe M, Lucas S, Mishler BD, Reski R, Grigoriev IV, Quatrano RS, Boore JL. The Physcomitrella genome reveals evolutionary insights into the conquest of land by plants. Science 2008;319:64-9. doi: 10.1126/science. 1150646

35. International Rice Genome Sequencing Project. The mapbased sequence of the rice genome. Nature 2005;436:793800. doi: 10.1038 /nature 03895

36. Phytozome [displayed 16 January 2014]. Available at http:// www.phytozome.com

37. Cambridge Healhtech Institute. -Omes and -omics glossary \& taxonomy [displayed 16 January 2014]. Available at http:// www.genomicglossaries.com/content/omes.asp

38. Ahsan N, Renaut J, Komatsu S. Recent developments in the application of proteomics to the analysis of plant responses to heavy metals. Proteomics 2009;9:2602-21. doi: 10.1002/ pmic. 200800935

39. Anderson L, Seilhamer J. A comparison of selected mRNA and protein abundances in human liver. Electrophoresis 1997;18:533-7. PMID: 9150937

40. Mazzucotelli E, Mastrangelo AM, Crosatti C, Guerra D, Stanca AM, Cattivelli L. Abiotic stress response in plants: When post-transcriptional and post-translational regulations control transcription. Plant Sci 2008;174:420-31. doi: 10.1016/j.plantsci.2008.02.00 
41. Hakeem KR, Chandna R, Ahmad P, Iqbal M, Ozturk M. Relevance of proteomic investigations in plant abiotic stress physiology. OMICS 2012;16:621-35. doi: 10.1089/ omi.2012.0041

42. Cobon GS. Verrills N., Papakostopoulos P, Eastwood H, Linnane AW. The proteomics of ageing. Biogerontology 2002;3:133-6. doi: 10.1023/A:1015240304287

43. Hirano H, Islam N, Kawasaki H. Techical aspects of functional proteomics in plants. Phytochemistry 2004;65:1487-9. PMID: 15276446

44. Timperio AM, Egidi MG, Zolla L. Proteomics applied on plant abiotic stresses: Role of heat shock proteins (HSP). J Proteomics 2008;71:391-411. doi: $10.1016 / \mathrm{j}$. jprot.2008.07.005

45. Swinbanks D. Government backs proteome proposal. Nature 1995;378:653. doi: 10.1038/378653a0

46. de Hoog CL, Mann M. Proteomics. Annu Rev Genomics Hum Genet 2004;5:267-93. doi: 10.1146/annurev. genom.4.070802.110305

47. Cuypers A, Vangronsveld J, Clijsters H. The redox status of plant cells (AsA and GSH) is sensitive to zinc imposed oxidative stress in roots and primary leaves of Phaseolus vulgaris. Plant Physiol Biochem 2001;39:657-64. doi: 10.1016/S0981-9428(01)01276-1

48. Aravind P, Prasad MNV. Zinc alleviates cadmium-induced oxidative stress in Ceratophyllum demersum L.: a free floating freshwater macrophyte. Plant Physiol Biochem 2003;41:391-7. doi: 10.1016/S0981-9428(03)00035-4

49. Horvat T, Vidaković-Cifrek Ž, Oreščanin V, Tkalec M, Pevalek- Kozlina B. Toxicity assessment of heavy metal mixtures by Lemna minor L. Sci Total Environ 2007;384:22938. doi: 10.1016/j.scitotenv.2007.06.007

50. Gratão PL, Monteiro CC, Antunes AM, Peres LEP, Azevedo RA. Acquired tolerance of tomato (Lycopersicon esculentum cv. Micro-Tom) plants to cadmium induced stress. Ann Appl B i o $122008 ; 153: 321-33$. d o i : 10.1111/j.1744-7348.2008.00299.x

51. Tkalec M, Prebeg T, Roje V, Pevalek-Kozlina, Ljubešić N. Cadmium induced responses in duckweed Lemna minor $\mathrm{L}$. Acta Physiol Plant 2008;30:881-90. doi: 10.1007/s11738008-0194-y

52. Hassan MJ, Zhang G, Wu F, Wie K, Chen Z. Zinc alleviates growth inhibition and oxidative stress caused by cadmium in rice. J Plant Nutr Soil Sci 2005; 168:255-61. doi: 10.1002/ jpln.200420403

53. Cvjetko P, Tolić S, Šikić S, Balen B, Tkalec M, VidakovićCifrek Ž, Pavlica M. Effect of copper on the toxicity and genotoxicity of cadmium in duckweed (Lemna minor L.) Arh Hig Rada Toksikol 2010;61:287-96. doi: 10.2478/100041254-61-2010-2059

54. Balen B, Tkalec M, Šikić S, Tolić S, Cvjetko P, Pavlica M, Vidaković-Cifrek Ž. Biochemical responses of Lemna minor experimentally exposed to cadmium and zinc. Ecotoxicology 2011;20:815-26. doi: 10.1007/s10646-011-0633-1

55. Ahsan N, Lee DG, Kim KH, Alam I, Lee SH, Lee KW, Lee $\mathrm{H}$, Lee BH. Analysis of arsenic stress-induced differentially expressed proteins in rice leaves by two-dimensional gel electrophoresis coupled with mass spectrometry. Chemosphere 2010;78:224-31. doi: 10.1016/j. chemosphere.2009.11.004

56. Ahsan N, Lee DG, Alam I, Kim PJ, Lee JJ, Ahn YO, Kwak SS, Lee I-J, Bahk JD, Kang KY, Renaut J, Komatsu S, Lee
BH. Comparative proteomic study of arsenic-induced differentially expressed proteins in rice roots reveals glutathione plays a central role during As stress. Proteomics 2008;8:3561-76. doi: 10.1002/pmic.200701189

57. Ahsan N, Lee SH, Lee DG, Lee H, Lee SW, Bahk JD, Lee $\mathrm{BH}$. Physiological and protein profiles alternation of germinating rice seedlings exposed to acute cadmium toxicity. C R Biol 2007;330:735-46. PMID: 17905393

58. Ahsan N, Lee DG, Lee SH, Kang KY, Lee JJ, Kim PJ, Yoon HS, Kim JS, Lee BH. Excess copper induced physiological and proteomic changes in germinating rice seeds. Chemosphere 2007;67:1182-93. doi: 10.1016/j. chemosphere.2006.10.075

59. Fecht-Christoffers MM, Braun HP, Lemaitre-Guillier C, Van Dorsselaer A, Horst WJ. Effect of manganese toxicity on the proteome of the leaf apoplast in cowpea. Plant Physiol 2003;133:1935-46. doi: 10.1104/pp.103.029215

60. Führs H, Hartwig M, Molina LE, Heintz D, Van Dorsselaer A, Braun HP, Horst WJ. Early manganese-toxicity response in Vigna unguiculata L. - a proteomic and transcriptomic study. Proteomics 2008;8:149-59. doi: 10.1002/ pmic. 200700478

61. Hossain Z, Hajika M, Komatsu S. Comparative proteome analysis of high and low cadmium accumulating soybeans under cadmium stress. Amino Acids 2012;43:2393-416. doi: 10.1007/s00726-012-1319-6

62. Lee K, Bae DW, Kim SH, Han HJ, Liu X, Park HC, Lim CO, Lee SY, Chung WS. Comparative proteomic analysis of the short-term responses of rice roots and leaves to cadmium. J Plant Physiol 2010;167:161-8. doi: 10.1016/j. jplph.2009.09.006

63. Pandey S, Rai R, Rai LC. Proteomics combines morphological, physiological and biochemical attributes to unravel the survival strategy of Anabaena sp.PCC7120 under arsenic stress. J Proteomics 2012;75:921-37. doi: 10.1016/j. jprot.2011.10.011

64. Requejo R, Tena M. Maize response to acute arsenic toxicity as revealed by proteome analysis of plant shoots. Proteomics 2006;6(Suppl 1):S156-62. PMID: 16534746

65. Sarry JE, Kuhn L, Ducruix C, Lafaye A, Junot C, Hugouvieux V, Jourdain A, Bastien O, Fievet JB, Vailhen D, Amekraz B, Moulin C, Ezan E, Garin J, Bourguignon J. The early responses of Arabidopsis thaliana cells to cadmium exposure explored by protein and metabolite profiling analyses. Proteomics 2006;6:2180-98. doi: 10.1002/pmic.200500543

66. Semane B, Dupae J, Cuypers A, Noben JP, Tuomainen M, Tervahauta A, Kärenlampi S, Van Belleghem F, Smeets K, Vangronsveld J. Leaf proteome responses of Arabidopsis thaliana exposed to mild cadmium stress. J Plant Physiol 2010;167:247-54. doi: 10.1016/j.jplph.2009.09.015

67. Zhou S, Sauvé R, Thannhauser TW. Proteome changes induced by aluminium stress in tomato roots. J Exp Bot 2009;60:1849-57. doi: 10.1093/jxb/erp065

68. Ahsan N, NakamuraT, Komatsu S. Differential responses of microsomal proteins and metabolites in two contrasting cadmium (Cd) accumulating soybean cultivars under $\mathrm{Cd}$ stress. Amino Acids 2012;42:317-27. doi: 10.1007/s00726010-0809-7

69. Hossain Z, Makino T, Komatsu S. Proteomic study of $\beta$-aminobutyric acid-mediated cadmium stress alleviation in soybean. J Proteomics 2012;75:4151-64. doi: 10.1016/j. jprot.2012.05.037 
70. Hradilová J, Rehulka P, Rehulková H, Vrbová M, Griga M, Brzobohatý B. Comparative analysis of proteomic changes in contrasting flax cultivars upon cadmium exposure. Electrophoresis 2010;31:421-31. doi: 10.1002/ elps. 200900477

71. Duressa D, Soliman K, Taylor R, Senwo Z. Proteomic analysis of soybean roots under aluminum stress international. Int J Plant Genomics 2011;2011:2825-31. doi: $10.1155 / 2011 / 282531$

72. Cho K, Torres NL, Subramanyam S, Deepak SA, Sardesai N, Han O, Williams CE, Ishii H, Iwahashi H, Rakwal R. Protein extraction/solubilization protocol for monocot and dicot plant gel-based proteomics. J Plant Biol 2006;49:41320. doi: 10.1007/BF03031120

73. Rose JKC, Bashir S, Giovannoni JJ, Jahn MM, Saravanan RS. Tackling the plant proteome: practical approaches, hurdles and experimental tools. Plant J 2004;39:715-33. doi: 10.1111/j.1365-313X.2004.02182.x

74. Jellouli N, Salem AB, Ghorbel A, Jouira HB. Evaluation of protein extraction methods for Vitis vinifera leaf and root. $\mathrm{J}$ Integr Plant Biol 2010;52:933-40. doi: 10.1111/j.1744-7909.2010. 00973.x

75. Isaacson T, Damasceno CM, Saravanan RS, He Y, Catalá C, Saladié M, Rose JK. Sample extraction techniques for enhanced proteomic analysis of plant tissues. Nat Protoc 2006;1:769-74. PMID: 17406306

76. Nouri MZ, Komatsu S. Comparative analysis of soybean plasma membrane proteins under osmotic stress using gelbased and LC MS/MS-based proteomics approaches. Proteomics 2010;10:1930-45. doi: 10.1002/pmic.200900632

77. Pavoković D, Križnik B, Krsnik-Rasol M. Evaluation of protein extraction methods for proteomic analysis of nonmodel recalcitrant plant tissues. Croat Chem Acta 2012;85:177-83. doi: 10.5562/cca1804

78. Komatsu S. Ahsan N. Soybean proteomics and its application to functional analysis. J Proteomics 2009;72:325-36. doi: 10.1016/j.jprot.2008.10.001

79. Sarma AD, Oehrle, NW, Emerich DW. Plant protein isolation and stabilization for enhanced resolution of two-dimensional polyacrylamide gel electrophoresis. Anal Biochem 2008;379:192-5. doi: 10.1016/j.ab.2008.04.047

80. Alvarez S, Berla BM, Sheffield J, Cahoon RE, Jez JM, Hicks LM. Comprehensive analysis of the Brassica juncea root proteome in response to cadmium exposure by complementary proteomic approaches. Proteomics 2009;9:2419-31. doi: $10.1002 /$ pmic. 200800478

81. Vannini C, Marsoni M, Domingo G, Antognoni F, Biondi S, Bracale M. Proteomic analysis of chromate-induced modifications in Pseudokirchneriella subcapitata. Chemosphere 2009;76:1372-9. doi: 10.1016/j. chemosphere.2009.06.022

82. Ritter A, Ubertini M, Romac S, Gaillard F, Delage L, Mann A, Cock JM, Tonon T, Correa JA, Potin P. Copper stress proteomics highlights local adaptation of two strains of the model brown alga Ectocarpus siliculosus. Proteomics 2010;10:2074-88. doi: 10.1002/pmic.200900004

83. Rodríguez-Celma J, Rellán-Alvarez R, Abadía A, Abadía J, López-Millán AF. Changes induced by two levels of cadmium toxicity in the 2-DE protein profile of tomato roots. J Proteomics 2010;73:1694-706. doi: 10.1016/j. jprot.2010.05.001
84. Sharmin SA, Alam I, Kim KH, Kim YG, Kim PJ, Bahk JD, Lee BH. Chromium-induced physiological and proteomic alterations in roots of Miscanthus sinensis. Plant Sci 2012;187:113-26. doi: 10.1016/j.plantsci.2012.02.002

85. Komatsu S, Wada T, Abaléa Y, Nouri MZ, Nanjo Y, Nakayama N, Shimamura S, Yamamoto R, Nakamura T, Furukawa K. Analysis of plasma membrane proteome in soybean and application to flooding stress response. J Proteome Res 2009;8:4487-99. doi: 10.1021/pr9002883

86. Agrawal GK, Bourguignon J, Rolland N, Ephritikhine G, Ferro M, Jaquinod M, Alexiou KG, Chardot T, Chakraborty N, Jolivet P, Doonan JH, Rakwal R. Plant organelle proteomics: Collaborating for optimal cell function. Mass Spectrom Rev 2011;30:I 772-853. doi: 10.1002/mas.20301

87. Eubel H, Braun HP and A Millar H. Blue-native PAGE in plants: a tool in analysis of protein-protein interactions. Plant Methods 2005;1:11. PMID: 16287510

88. Xi J, Wang X, Li S, Zhou X, Yue L, Fan J, Hao D. Polyethylene glycol fractionation improved detection of low-abundant proteins by two dimensional electrophoresis analysis of plant proteome. Phytochemistry 2006;67:2341-8. doi: 10.1016/j.phytochem.2006.08.005

89. Baracat-Pereira MC, de Oliveira Barbosa M, Magalhães Júnior MJ, Carrijo LC, Games PD, Almeida HO, Sena Netto JF, Rodrigues Pereira M, de Barros EG. Separomics applied to the proteomics and peptidomics of low-abundance proteins: Choice of methods and challenges - A review. Gen Mol Biol 2012;35:283-91. doi: 10.1590/S141547572012000200009

90. Cho J-H, Hwang H, Cho M-H, Kwon Y-K, Jeon J-S, Bhoo $\mathrm{SH}, \mathrm{Hahn}$ T-R. The effect of DTT in protein preparations for proteomic analysis: removal of a highly abundant plant enzyme, ribulose bisphosphate carboxylase/oxygenase. J Plant Biol 2008;51:297-301. doi: 10.1007/BF03036130

91. Krishnan HB, Natarajan SS. A rapid method for depletion of Rubisco from soybean (Glycine max) leaf for proteomic analysis of lower abundance proteins. Phytochemistry 2009;70:1958-64. doi: 10.1016/j.phytochem.2009.08.020

92. Natarajan SS, Krishnan HB, Lakshman S, Garrett WM. An efficient extraction method to enhance analysis of low abundant proteins from soybean seed. Anal Biochem 2009;394:259-68. doi: 10.1016/j.ab.2009.07.048

93. Vertommen A, Møller AL, Cordewenerd JHG, Swennen R, Panis B, Finnie C, America AHP, Carpentiera SC. A workflow for peptide-based proteomics in a poorly sequenced plant: A case study on the plasma membrane proteome of banana. J Proteomics 2011;74:1218-29. doi: 10.1016/j. jprot.2011.02.008

94. Azarkan M, Huet J, Baeyens-Volant D, Looze Y, Vandenbussche G. Affinity chromatography: A useful tool in proteomics studies. J Chromatogr B Analyt Technol Biomed Life Sci 2007;849:81-90. PMID: 17113368

95. Fang X, Zhang W. Affinity separation and enrichment methods in proteomic analysis. J Proteomics 2008;71:284303. doi: 10.1016/j.jprot.2008.06.011

96. Fröhlich A, Lindermayr C. Deep insights into the plant proteome by pretreatment with combinatorial hexapeptide ligand libraries. J Proteomics 2011;74:1182-9. doi: 10.1016/j. jprot.2011.02.019

97. Fröhlich A, Gaupels F, Sarioglu H, Holzmeister C, Spannagl M, Durner J, Lindermayr C. Looking deep inside: Detection of low-abundance proteins in leaf extracts of Arabidopsis 
and phloem exudates of pumpkin. Plant Physiol 2012;159:902-14. doi: 10.1104/pp.112.198077

98. Gallagher SR. One-dimensional SDS gel electrophoresis of proteins. Curr Protoc Mol Biol 2006;75:10.2.1-10.2A.37. doi: 10.1002/0471142727.mb1002as75

99. Klose J. From 2-D electrophoresis to proteomics. Electrophoresis 2009;30:S142-9. doi: 10.1002/ elps.200900118

100. Peharec Štefanić P, Šikić S, Cvjetko P, Balen B. Cadmium and zinc induced similar changes in protein and glycoprotein patterns in tobacco (Nicotiana tabacum L.) seedlings and plants. Arh Hig Rada Toksikol 2012;63:321-35. doi: 10.2478/10004-1254-63-2012-2173

101. Gallagher SR. One-dimensional SDS gel electrophoresis of proteins. Curr Protoc Cell Biol 2007;37:6.1.1-6.1.38. 10.1002/0471143030.cb0601s37

102. O'Farrell PH. High resolution two-dimensional electrophoresis. J Biol Chem 1975;250:4007-21. PMID 236308

103. Friedman D, Hoving S, Westmeier R. Isoelectric focusing and two-dimensional gel electrophoresis. Methods Enymol 2009;463:515-40. doi: 10.1016/S0076-6879(09)63030-5

104. Bjellqvist B, Ek K, Righetti GP, Gianazza E, Görg A, Westermeier R, Postel W. Isoelectric focusing in immobilized $\mathrm{pH}$ gradients: principle, methodology and some applications. J Biochem Biophys Methods 1982;6:317-39. PMID 7142660

105. Ünlü M, Morgan ME, Minden JS. Difference gel electrophoresis: a single gel method for detecting changes in protein extracts. Electrophoresis 1997;18:2071-7. doi: 10.1002/elps.1150181133

106. Tonge R, Shaw J, Middleton B, Rowlinson R, Rayner S, Young J, Posgnan F, Hawkins E, Currie I, Davison M. Validation and development of fluorescence two-dimensional differential gel electrophoresis proteomics technology. Proteomics 2001;1:377-96. PMID: 11680884

107. Schägger H, von Jagow G. Blue native electrophoresis for isolation of membrane protein complexes in enzymatically active form. Anal Biochem 1991;199:223-31. doi: 10.1016/0003-2697(91)90094-a

108. Schägger H, Cramer W A, von Jagow G. Analysis of molecular masses and oligomeric states of protein complexes by blue native electrophoresis and isolation of membrane protein complexes by two-dimensional native electrophoresis. Anal Biochem 1994;217:220-30. doi: 10.1006/ abio.1994.1112

109. Reisinger V, Eichacker LA. Analysis of membrane protein complexes by Blue Native PAGE. Proteomics 2006;6(Suppl 2):6-15. PMID: 17031799

110. Nijtmans LG, Henderson NS, Holt IJ. Blue native electrophoresis to study mitochondrial and other protein complexes. Methods 2002;26:327-34. PMID: 12054923

111. Führs H, Behrens C, Gallien S, Heintz D, Van Dorsselaer A, Braun HP, Horst WJ. Physiological and proteomic characterization of manganese sensitivity and tolerance in rice (Oryza sativa) in comparison with barley (Hordeum vulgare). Ann Bot 2010;105:1129-40. doi: 10.1093/aob/ meq046

112. Fagioni M, D'Amici GM, Timperio AM, Zolla L. Proteomic analysis of multiprotein complexes in the thylakoid membrane upon cadmium treatment. J Proteome Res 2009;8:310-26. doi: 10.1021/pr800507x
113. GelAnalyzer [displayed 20 January 2014]. Available at http:// www.gelanalyzer.com

114. GelScape [displayed 20 January 2014]. Available at http:// www.gelscape.ualberta.ca

115. Li F, Shi J, Shen C, Chen G, Hu S, Chen Y. Proteomic characterization of copper stress response in Elsholtzia splendens roots and leaves. Plant Mol Biol 2009;71:251-63. doi: $10.1007 / \mathrm{s} 11103-009-9521-\mathrm{y}$

116. Zhang H, Lian C, Shen Z. Proteomic identification of small, copper-responsive proteins in germinating embryos of Oryza sativa. Ann Bot 2009;103:923-30. doi: 10.1093/aob/mcp012

117. Duquesnoy I, Goupil P, Nadaud I, Branlard G, PiquetPissaloux A, Ledoigt G. Identification of Agrostis tenuis leaf proteins in response to $\mathrm{As}(\mathrm{V})$ and $\mathrm{As}(\mathrm{III})$ induced stress using a proteomics approach. Plant Sci 2009;176:206-13. doi: 10.1016/j.plantsci.2008.10.008

118. Zhen Y, Qi JL, Wang SS, Su J, Xu GH, Zhang MS, Miao L, Peng XX, Tian D, Yang YH. Comparative proteome analysis of differentially expressed proteins induced by Al toxicity in soybean. Physiol Plant 2007;131:542-54. doi: 10.1111/j.1399-3054.2007.00979.x

119. Yang Q, Wang Y, Zhang J, Shi W, Qian C, Peng X. Identification of aluminium-responsive proteins in rice roots by a proteomic approach: cysteine synthase as a key player in Al response. Proteomics 2007;7:737-49. PMID:17295357

120. Wang R, Gao F, Guo BQ, Huang JC, Wang L, Zhou YJ. Short-term chromium-stress-induced alterations in the maize leaf proteome. Int J Mol Sci 2013;14:11125-44. doi: 10.3390/ ijms140611125

121. Alves M, Moes S, Jenö P, Pinheiro C, Passarinho J, Ricardo CP. The analysis of Lupinus albus root proteome revealed cytoskeleton altered features due to long-term boron deficiency. J Proteomics 2011;74:1351-63. doi: 10.1016/j. jprot.2011.03.002

122. Ong SE, Blagoev B, Kratchmarova I, Kristensen DB, Steen H, Pandey A, Mann M. Stable isotope labelling by amino acids in cell culture, SILAC, as a simple and accurate approach to expression proteomics. Mol Cell Proteomics 2002;1:376-86. doi: 10.1074/mcp.M200025-MCP200

123. Ross PL, Huang YN, Marchese JN, Williamson B, Parker K, Hattan S, Khainovski N, Pillai S, Dey S, Daniels S, Purkayastha S, Juhasz P, Martin S, Bartlet-Jones M, He F, Jacobson A, Pappin DJ. Multiplexed protein quantitation in Saccharomyces cerevisiae using amine-reactive isobaric tagging reagents. Mol Cell Proteomics 2004;3:1154-69. PMID: 15385600

124. Smaczniak C, Li N, Boeren S, America T, van Dongen W, Goerdayal SS, de Vries S, Angenent GC, Kaufmann K. Proteomics-based identification of low-abundance signalling and regulatory protein complexes in native plant tissues. Nature Protocols 2012;7:2144-58. doi: 10.1038/ nprot.2012.129

125. Schütz W, Hausmann N, Krug K, Hampp R, Macek B. Extending SILAC to proteomics of plant cell lines. Plant Cell 2011;23:1701-5. doi: 10.1105/tpc.110.082016

126. Lucker J, Laszczak M, Smith D, Lund ST. Generation of a predicted protein database from EST data and application to iTRAQ analyses in grape (Vitis vinifera $\mathrm{cv}$ Cabernet Sauvignon) berries at ripening initiation. BMC Genomics 2009;10:50. doi: 10.1186/1471-2164-10-50

127. Arike L, Valgepea K, Peil L, Nahku R, Adamberg K, Vilu R. Comparison and applications of label-free absolute proteome 
quantification methods on Escherichia coli. J Proteomics 2012;75:5437-48. doi: 10.1016/j.jprot.2012.06.020

128. Thelen JJ, Peck SC. Quantitative proteomics in plants: choices in abundance. Plant Cell 2007;19:3339-46. doi: 10.1105/tpc.107.053991

129. Patterson J, Ford K, Cassin A, Natera S, Bacic A. Increased abundance of proteins involved in phytosiderophore production in boron-tolerant barley. Plant Physiol 2007;144:1612-31. doi: 10.1104/pp.107.096388

130. Schneider T, Schellenberg M, Meyer S, Keller F, Gehrig P, Riedel K, Lee Y, Eberl L, Martinoia E. Quantitative detection of changes in the leaf-mesophyll tonoplast proteome in dependency of a cadmium exposure of barley (Hordeum vulgare L.) plants. Proteomics 2009;9:2668-77. doi: 10.1002/ pmic. 200800806

131. Finka A, Goloubinoff P. Proteomic data from human cell cultures refine mechanisms of chaperone-mediated protein homeostasis. Cell Stress Chaperones 2013;18:591-605. doi: 10.1007/s12192-013-0413-3

132. Wang W, Vinocur B, Shoseyov O, Altman A. Role of plant heat-shock proteins and molecular chaperones in the abiotic stress response. Trends Plant Sci 2004;9:244-52. doi: 10.1007/s12192-013-0413-3
133. Verbruggen N, Hermans C, Schat H. Mechanisms to cope with arsenic or cadmium excess in plants. Curr Opin Plant Biol 2009;12:364-72. doi: 10.1016/j.pbi.2009.05.001

134. Remmerie N, De Vijlder, T, Laukens K, Dang TH., Lemiere F, Mertens I. Next generation functional proteomics in nonmodel plants: a survey on techniques and applications for the analysis of protein complexes and post-translational modifications. Phytochemistry 2011;72:1192-218. doi: 10.1016/j.phytochem.2011.01.003

135. Champagne A, Boutry M. Proteomics of nonmodel plant species. Proteomics 2013;13:663-73. doi: 10.1002/ pmic. 201200312

136. Vanderschuren H, Lentz E, Zainuddin I, Gruissem W. Proteomics of model and crop plant species: Status, current limitations and strategic advances for crop improvement. J Prot 2013;93:5-19 doi: 10.1016/j.jprot.2013.05.036

137. Galperin MY, Koonin E V. From complete genome sequence to 'complete' understanding? Trends Biotechnol 2010;28:398406. doi: 10.1016/j.tibtech.2010.05.006

138. Eapen S, D'Souza SF. Prospects of genetic engineering of plants for phytoremediation of toxic metals. Biotechnol Adv 2005;23:97-114. PMID: 15694122

139. Aken BV. Transgenic plants for phytoremediation: helping nature to clean up environmental pollution. Trends Biotechnol 2008;26:225-7. doi: 10.1016/j.tibtech.2008.02.001 


\section{Sažetak}

\section{Proteomika u istraživanjima toksičnosti teških metala u biljaka}

Biljke su neprestano izložene različitim čimbenicima abiotičkog i biotičkog stresa koji nepovoljno utječu na njihovu produktivnost. Teški metali kao česti zagađivači okoliša vrlo nepovoljno djeluju na sva živa bića, uključujući biljke, životinje i ljude. Poznato je da teški metali mogu mijenjati ekspresiju biljnih proteina. Proteine ubrajamo u biološki vrlo važne makromolekule čija je aktivnost u stanici izravno ovisna o posttranslacijskim modifikacijama, koje nije moguće pratiti na razini genoma. Stoga je nužno provoditi proteomska istraživanja kako bi se razotkrila prisutnost i uloga proteina u različitim vrstama okolišnog stresa. U ovom radu sažete su različite tehnike i metode istraživanja učinaka teških metala na biljni proteom, uključujući i sažet osvrt na složene mehanizme odgovora biljke na stres izazvan teškim metalima.

KLJUČNE RIJEČI: dvodimenzionalna elektroforeza; masena spektrometrija; proteinski biomarkeri; proteom; teški metali

\section{CORRESPONDING AUTHOR:}

Biljana Balen

Associate Professor

Department of Molecular Biology

Faculty of Science, University of Zagreb

Horvatovac 102a, Zagreb, Croatia

E-mail:bbalen@zg.biol.pmf.hr 